\title{
Discovering the geoeducation value of the lower basin Chicamocha River, Santander (Colombia)
}

\begin{abstract}
The banks of the Chicamocha River, as in most rivers, generally serve as the basis for the development of human settlements. However, the anthropogenic activity has been deteriorating its environment and water quality, generating environmental and human health problems, as well as difficulty in meeting the demand for water. This article highlights the role of geoeducation in the transfer of knowledge about watersheds, in particular the Lower Basin Chicamocha River, as well as the design and development of pedagogical strategies focused on their sustainable development, based on awareness of the importance of hydric resources, interconnecting children, youth and adults with the natural environment. In this way, it is expected to mitigate the impact generated by urban expansion and waste disposal. The restoration of the Chicamocha River could be thought of from a perspective in which there is a greater recognition of the interconnected benefits that restored ecosystems can provide to society.
\end{abstract}

Keywords: chicamocha river, ecosystems, urban expansión, geoeducation, restoration
Volume 3 Issue $6-2019$

\author{
Carlos Alberto Ríos-Reyes,' Ricardo \\ Amorocho-Parra, ' William Mantilla-Orduz,' \\ Carlos Alberto Villarreal-jaimes,' Laura Sofía \\ Puentes Argüello,' Lizeth Natalia García \\ Arenas,' Jenny Paola García Lobo,' Karen \\ Tatiana Patiño Villabona,' Oscar Mauricio \\ Castellanos Alarcón ${ }^{2}$ \\ 'Universidad Industrial de Santander, Bucaramanga, Colombia \\ ${ }^{2}$ Universidad de Pamplona, Villa del Rosario, Colombia
}

Correspondence: Carlos Alberto Ríos-Reyes, Universidad Industrial de Santander, Bucaramanga, Colombia, Email caros@uis.edu.co

Received:September 17, 2019 | Published: November 01, 2019

\section{Introduction}

Colombia is one of the countries that offers the greatest water supply in the world, with the Magdalena, Amazonas, Cauca, Guaviare, Putumayo and Caquetá rivers being the most important. However, the Ministry of Environment estimates that half of the water resources have water quality problems due to anthropogenic activity. The Global Water Partnership recognizes the watershed as the most suitable territorial unit for planning and management of water resources. ${ }^{1}$ The Chicamocha River, considered one of the most important water sources in the region, crosses the centraleastern region of Colombia (Figure 1). It is born at the confluence of the Tuta and Jordán rivers (Department of Boyacá), in the Eastern Cordillera of the Colombian Andes, and ends its journey by joining the Suarez River to form the Sogamoso River (tributary of Magdalena river). The Chicamocha River Canyon, which is characterized by a marvelous landscape, is the result of a sequence of events that have occurred since the Precambrian period $(945 \pm 140 \mathrm{Ma})$, working on the oldest crystalline basement rocks traditionally divided into the following geological units: Bucaramanga Gneiss Complex, Silgará Formation and Orthogneiss, which were cut by several igneous bodies of Paleozoic-Jurassic age a $^{2-3}$ and smaller Cretaceous intrusive bodies, which form part of the Santander Plutonic Complex. These basement rocks, which have been studied by several authors, ${ }^{3-8}$ are unconformably overlain by unmetamorphosed rocks of the Middle Devonian Floresta Formation. Carboniferous and Permian clastic to calcareous sediments unconformably overlay this unit. Due to pre-Cretaceous erosional events, these Paleozoic sequences are restricted in their occurrence. ${ }^{9}$ Post-Paleozoic sediments, which overlay the Upper Paleozoic marine sediments, include the Bocas and Jordán formations. The latter consists of fine-grained red beds with interlayered volcanic rocks and intrusive clasts and is discordantly overlain by the red bed sequence of the Jurassic Girón Formation. Cretaceous sedimentary rocks are preserved as erosional relicts. The NW-trending Bucaramanga Fault represents the main tectonic structure, which separates the Precambrian Bucaramanga Gneiss Complex from the Triassic-Jurassic Pescadero and Mogotes batholiths. The large variety of and complexity of several potential geosities of stratigraphic, geomorphological, mineralogical, petrological or tectonic interest, together with the quality of landscapes and exposure of the outcrops, makes the Chicamocha River Canyon a territory with great scientific and educational potential. The objective of this work is to promote education and awareness about the importance of watersheds, in particular the Lower Basin Chicamocha River (LBCR), in students from elementary to university levels based on the design and development of several geoeducation activities with the overall goal of expanding watershed education and awareness throughout the LBCR.

\section{Physiographic characteristics of the LBCR}

The majesty of the Chicamocha River Canyon is unique in Latin America. The climatic conditions of this arid enclave are directly related to the local topography, because in this area the Eastern Cordillera of the Colombian Andes bifurcates into two mountainous complexes that surround the river and act as a barrier to the rains and humid currents that come from the Orinoquia and the Magdalena River Valley. ${ }^{10}$ The Chicamocha River Basin is subdivided into the high, medium and low basins. The LBCR, which is of interest in the present study, crosses several municipalities of the Department of Santander. The LBCR is characterized in the sector where crystalline rocks out cropping by having a straight and braided river channel, the deposits 
are mainly of lateral and longitudinal bars typical of braided channels, is located in a sector with steep slopes and high slopes forming valleys incised in "V", in the sector where sedimentary rocks out cropping the channel is meandering, that erodes into a sector and deposits on the opposite side, is located in a sector with steep slopes and high slopes forming incised valleys with deep cliffs on both sides, low vegetation of arid and very scarce lands. The climate is predominantly dry, with an average annual temperature of $25.4-28.0^{\circ} \mathrm{C}$, and with scarce and seasonal periods of precipitation with an average annual precipitation of $731 \mathrm{~mm},{ }^{11-14}$ taking into account that the LBCR is n intramontane sector, which is characterized by surrounding areas with abundant vegetation and wet and rainy weather. A possible explanation of this variation of the climate or presence of dry and arid microclimate in the lower basin is due to the hot air currents that come from the Middle Valley of the Magdalena River ${ }^{15}$ that in the area displace the wind cold and humid coming from the surrounding mountain ranges upwards and causing a climatic barrier that facilitates the aridity in the area and also favored by the high slopes of the surrounding mountains and hills. In the future, climate change could negatively influence the Chicamocha River Basin, with higher temperatures causing long and severe droughts, which could affect the water supply. On the other hand, the accelerated expansion of urban centres would generate great concern about how the Chicamocha River could meet the demand for water. In addition, the composition of the rocks of the LBCR does not allow percolation of meteoric waters or the formation of aquifers or groundwater currents that favor the generation of thick soils, but the high fracturing of the rocks favors the presence of denudational and erosive processes that carve the slopes and generate the high slopes. The LBCR is the result of various natural factors such as the tectonic activity and the action of weathering agents, which have led to fracturing and the formation of slope deposits. The Chicamocha River and its tributaries have shaped the relief through deep valleys carved by the action of the deposit material as it is removed and transported. Undoubtedly, the size, topography and geological complexity of this region make it a place of exceptional geomorphological beauty (Figure 2). A magnific view of the Chicamocha River Cayon is shown in Figure 2A. Note the serrated hills with intense and active erosionon the crystalline basement of the Santander Massif. Figure 2B illustrates geomorphological aspects of the LBCR, with contrasting lithologies of crystalline igneous and metamorphic rocks developing valleys incised in "V" and sedimentary rocks with tight and steep valleys, although in both cases, the river is influenced by a fault system. Figure $2 \mathrm{C}$ shows a view of Chicamocha River Canyon between Los Santos and Villanueva plateaus, which are dissected by faults. Here, the Chicamocha River has eroded Jurassic and Cretaceous sedimentary rocks. Braided reach of the Chicamocha River on metamorphic rocks with subparallel drainage is observed in Figure 2D. The Chicamocha River Canyon is the result of the erosion caused by the Chicamocha River, which erosional forces created incise valleys and deep cliffs on both sides (Figure 2E). Note the meandering trace with point bars, developing a canyon with vertical slopes in Jurassic to Cretaceous sedimentary rocks. Figure 2F shows a valley in "V" on igneous rocks of the Pescadero Granite. Anthropogenic activity has modified the riverbed due to the gravel and sand mining (Figure 2G). Note the straight riverbed, which is modified by the aggregate rocks plant. Chicamocha River Canyon at the confluence of the Chicamocha and Suárez rivers to form the Sogamoso River (Figure 2H).

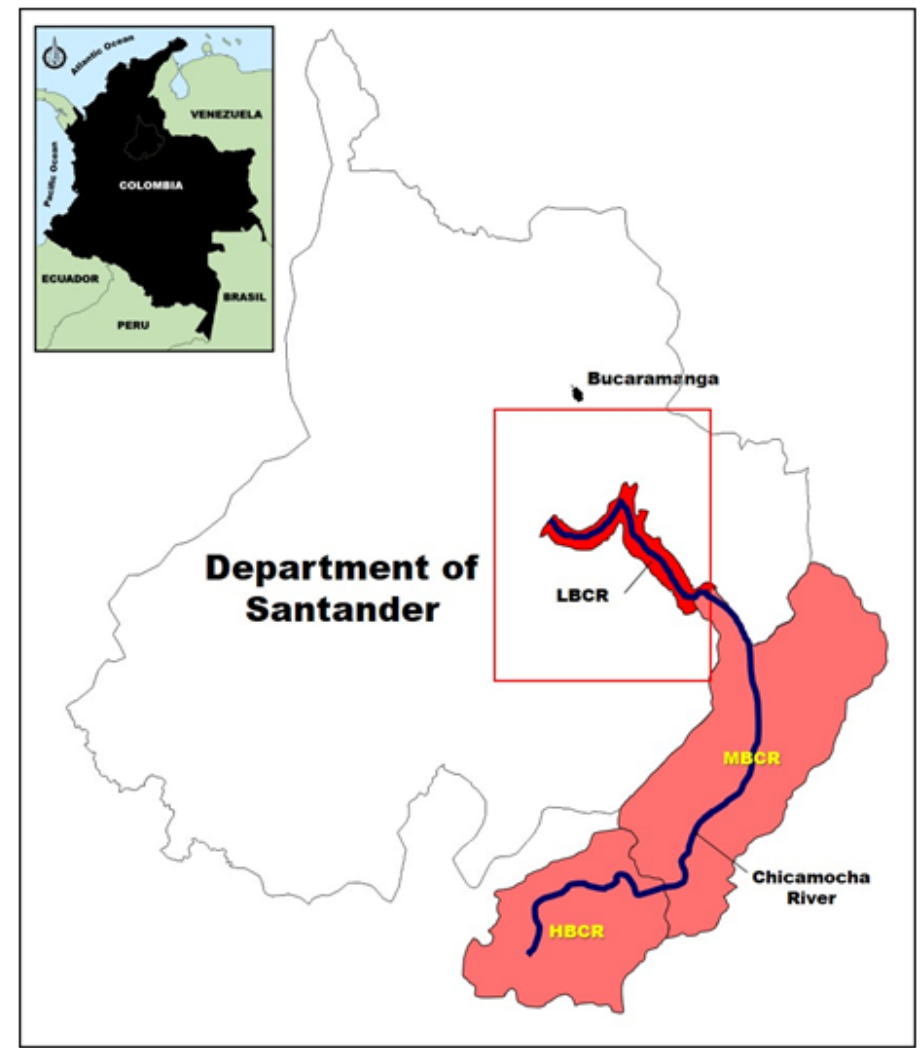

Figure I Geographical location of the LBCR (in red color). LBCR, Low Basin Chicamocha River; MBCR, Middle Basin Chicamocha River; HBCR, High Basin Chicamocha River. 

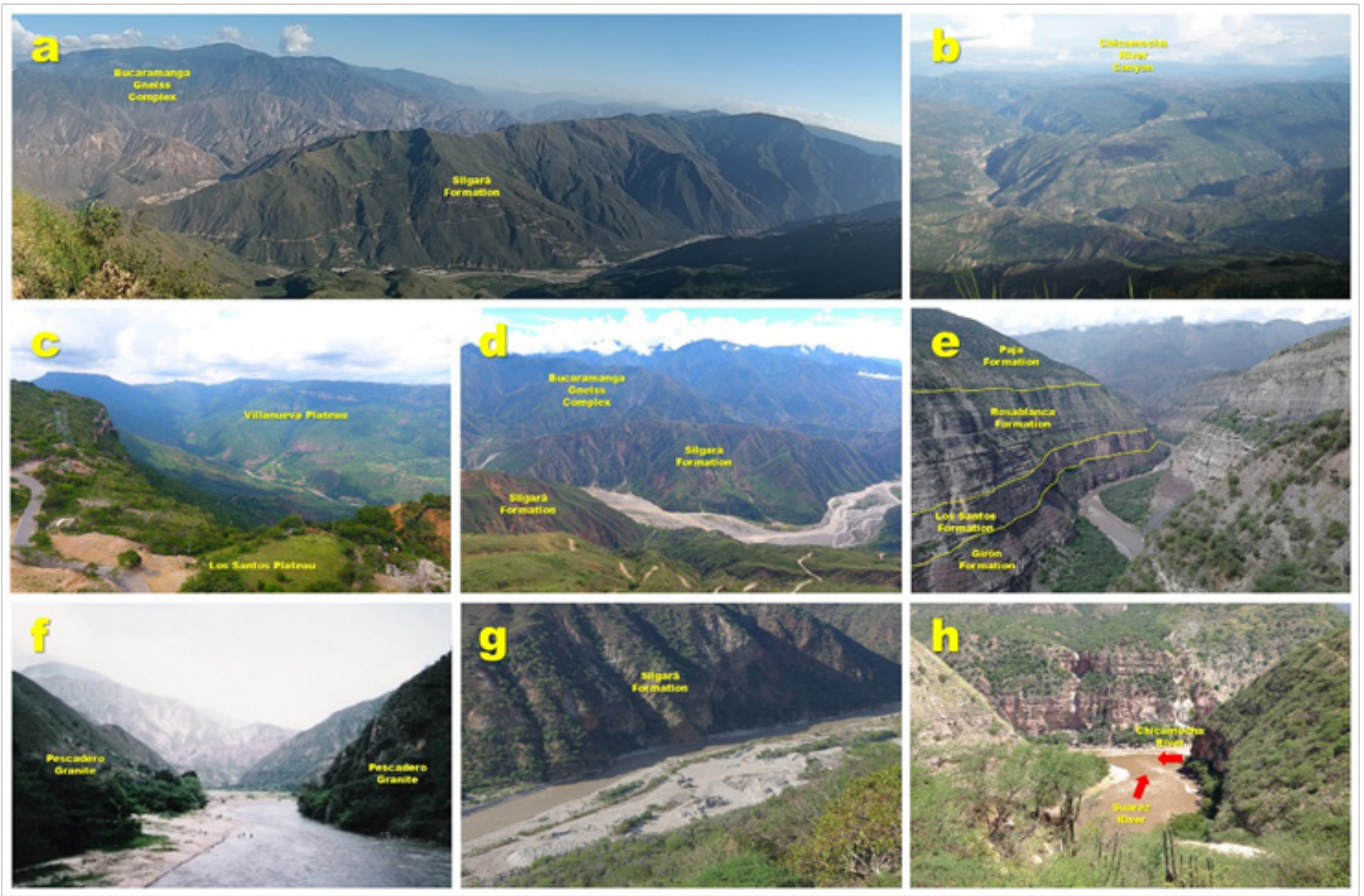

Figure 2 Main physiographic aspects of the LBCR.

\section{Natural heritage}

The LBCR is characterized by presenting valuable attributes of the natural heritage of our territory. The Chicamocha River has contributed to the modeling of the current landscape of the Chicamocha River Canyon region with a peculiar relief consisting of plateaus separated by deep and abrupt valleys cut in sedimentary and crystalline rocks. ${ }^{16}$ The LBCR is extremely rich in geodiversity and records rocks, geological history and processes from Precambrian to present. It is the result of erosion on the riverbed, with the formation of large defiles on both sides. This territory has been affected by tectonic movements, whose manifestations are expressed in the numerous faults and zones of high seismicity in the Mesa de Los Santos. In addition, it encompasses special places that exemplify geological topics such as the early evolution of the Earth's crust, some relevant mineral manifestations associated with igneous and metamorphic processes, representative sedimentary and fossilization processes, as well as recent river dynamics that has contributed greatly to landscape modeling. The Chicamocha River Canyon is characterized by the predominance of slopes greater than $15 \%$, superficial soils and mulberry and deciduous vegetation coverings with one or two thin strata of foliage, with low rainfall and moisture retention capacity. ${ }^{11}$ It is a region with a rich biodiversity and unique flora and fauna, representing from the biological point of view a laboratory of constant fighting of the species against extreme climatic factors that determine arid environments. The most important species in the regional vegetation Stenocereus griseus, Lippia origanoides and Prosopis juliflora. ${ }^{12,17}$ These environments generate a high diversity and a considerable number of endemic and sensitive species vulnerable to changes of anthropic origin, such as Cavanillesia chicamochae (Ceiba barrigona) and Thryophilus nicefori (Niceforo's Cucarachero).

\section{Watershed analysis}

During the watershed analysis, the use of DEM and raster data operations is used to delineate the watersheds and generate characteristics such as streams, stream networks, catchment areas, basins, etc. ${ }^{18}$ In general; watershed boundaries are drawn manually with the help of a topographic map based on topographic features on the map to determine how to define such delimitation. However, the use of specialized software in geographic information systems (GISs) has facilitated this process. The delineation of a watershed can take place at different spatial scales. The watershed analysis can be applied in the management and planning of natural resources, in hydrological modeling, in flood prediction modeling or in management programs. ${ }^{18}$ A delineating of the LBCR requires following several steps, which generate (1) DEM to observe the relief and hillslope, and fluvial drainage basin (Figure 3A); (2) Slope displaying the measures and objects (Figure 3B); slope metering is required in detailed field survey; (3) Aspect showing the flow direction, potentially humid zones and slope trending (Figure 3C); (4) Colored shaded showing the variety and richness of the geomorphological units; a river network can be observed (Figure 3D). 

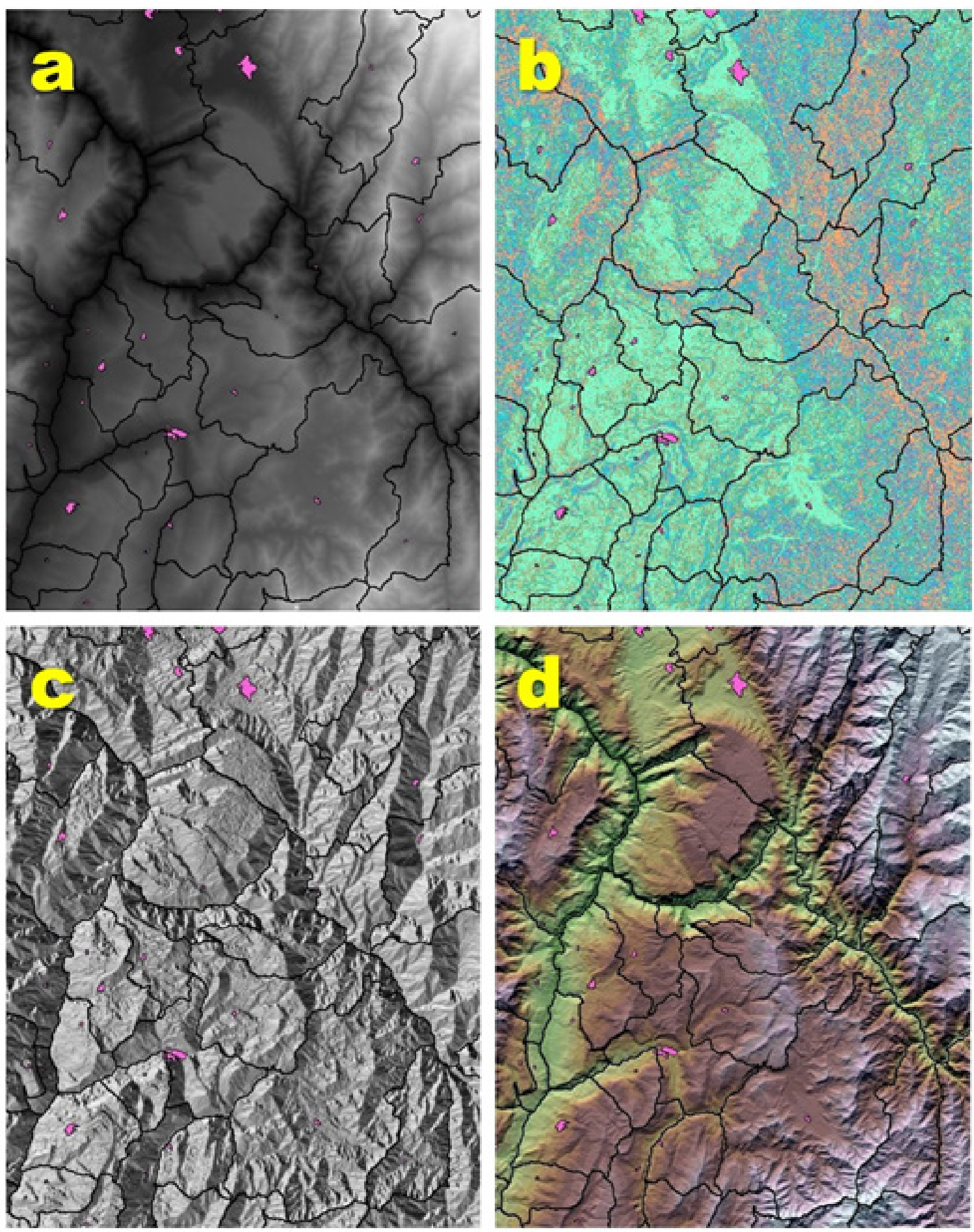

Figure 3 Watershed analysis of the LBCR based on (A) DEM; (B) Slope; (C) Aspect and (D) color shaped. DEM source: EarthExplorer. ${ }^{19}$

For the hydrological analysis of the basin, the analysis of the river flow is necessary, for which it is necessary to take data on maximum flows in established return periods; data that are taken to determine the river flow levels for establish possible threats or geopotentials. The Chicamocha River shows an influence with bimodal variation, that is, two periods in which the river has a higher flow and two periods in which the level of the river falls, which is also known as drought. This variation is directly related to the weather and precipitation periods. In the months of April to June and September to November is when the precipitation is greater in the area, which generates the increase in flow, which gives an average of $196 \mathrm{~m}^{3} / \mathrm{s}$ for these times. During the dry period, the flow drops to an average of $80 \mathrm{~m}^{3} / \mathrm{s}$, leaving evidence of sediment transport that the river has. ${ }^{15}$ 


\section{Geohazards associated with the LBCR}

The following geohazards occurring in the LBCR: seismic activity, torrents, flooding, fluvial erosion, debris flows and fall rocks and landslides, rills and gullies, fair forests and droughts. These natural phenomena generate threats on the local communities, natural and cultural heritage and unique ecosystems of the region. These high to very high range geohazards are enhanced due to anthropogenic activity and poor administrative management of local government.

\section{Contamination in the Chicamocha River}

Currently, there are numerous environmental problems, although one of the most worrying is the contamination of the water sources. This situation has become more alarming in recent years with the increase in population in urban areas, making the demand for water sources much higher. Watershed communities worldwide face environmental issues like flooding, decreasing water quality, and loss in ecosystem services. ${ }^{20}$ Ekness and Randhir ${ }^{21}$ carried out a study to quantify relationships that exist between climatic variables and vegetative activity, on runoff in watersheds. Urban development rarely sympathizes with its surroundings and generally overlooks the value of functional aquatic ecosystems. ${ }^{22}$ Consequently, urbanization is considered to be one of the most dramatic alterations of ecosystems, ${ }^{23}$ which occurs as a result of the combination of several factors, such as increase in impervious surfaces, channel modification, disconnection of rivers and floodplains, high water demand and increase in contaminants. ${ }^{24}$ Land use and hydrological changes associated with urbanization can also affect the sediment regime and morphology of the Chicamocha River as suggested by previous studies. ${ }^{25}$ The Chicamocha River represents a source of water supply, although anthropogenic sources of contaminants from mining, agriculture, domestic and industrial wastes have been affecting its water quality. The contamination of the Chicamocha River, as well as the environment of the basin, the loss of fauna and flora as protective elements and quality of life, deteriorate the ecosystem and, therefore, the quality of life of its inhabitants. ${ }^{26}$ The Chicamocha River is one of the most contaminated rivers in Colombia, ${ }^{27}$ carrying serious consequences in its channel and serious risks for populations that depend on it. The contamination of the Chicamocha River needs to be addressed urgently by taking the necessary attention measures to mitigate current risks, which should include monitoring stations to assess water quality, as the lack of preventive and corrective environmental measures has promoted progressive degradation of water quality until current pollution levels are reached. It is essential to have a sense of belonging and awareness about the situation of the LBCR, as there is a lack of knowledge or concern about water sources in general. The lack of awareness has generated the indiscriminate disposal of waste that has gradually deteriorated water quality. The Chicamocha River, as well as most of the rivers worldwide, faces a series of environmental problems that affect water quality despite the fact that more than half of the drinking water for human consumption comes from the rivers. There are a set of stakeholders that have both positive and negative impacts on rivers as shown in Figure 4. Such stakeholders cause and are affected by a number of activities and their outputs (water use, health, liveability, transport, recreation, food, disaster risks, etc) ${ }^{28}$

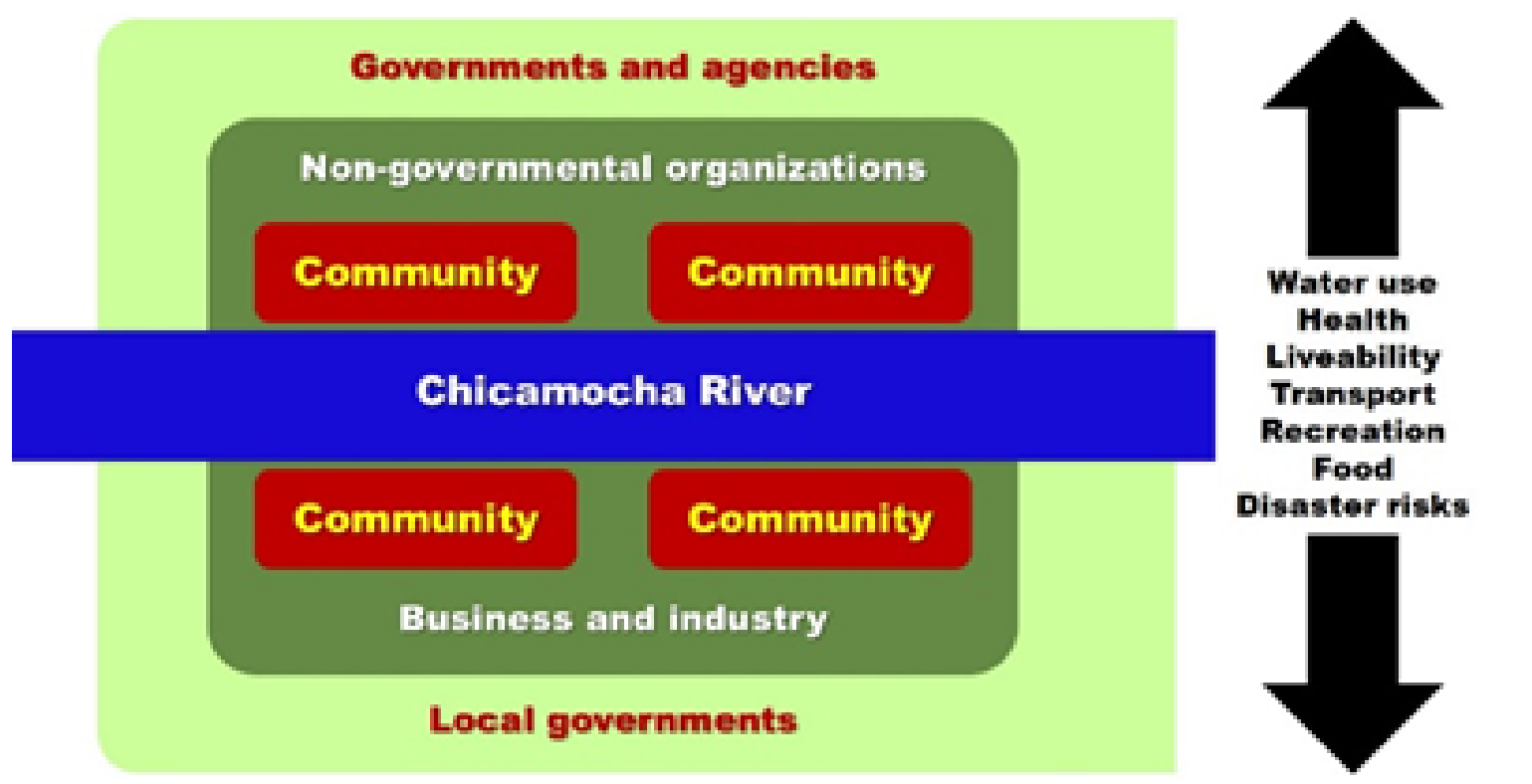

Figure 4 Impacts and causes of contamination of the Chicamocha River.

The LBCR region has been of great importance not for studying the geological and geomorphological aspects but also for developing extractive activities. The exploitation of gravel and sand in the Chicamocha River (Figure 5A) generate a negative impact in the riverbed, which is straight where is operating the rock aggregates plant, and in the geomorphology and landscape of the Chicamocha River Canyon. However, it shows a positive socio-economic impact as most of the rock aggregate used in the metropolitan area of Bucaramanga come from this plant. Figure 5B shows the exploitation of gypsum from sedimentary rocks of the Cretaceous Rosablanca Formation and the disposal of mining wastes on the Banks of the river contributing to its contamination. Recreational opportunities such as fishing, canoeing or boating are carrying out along the river (Figure $5 \mathrm{C})$. 

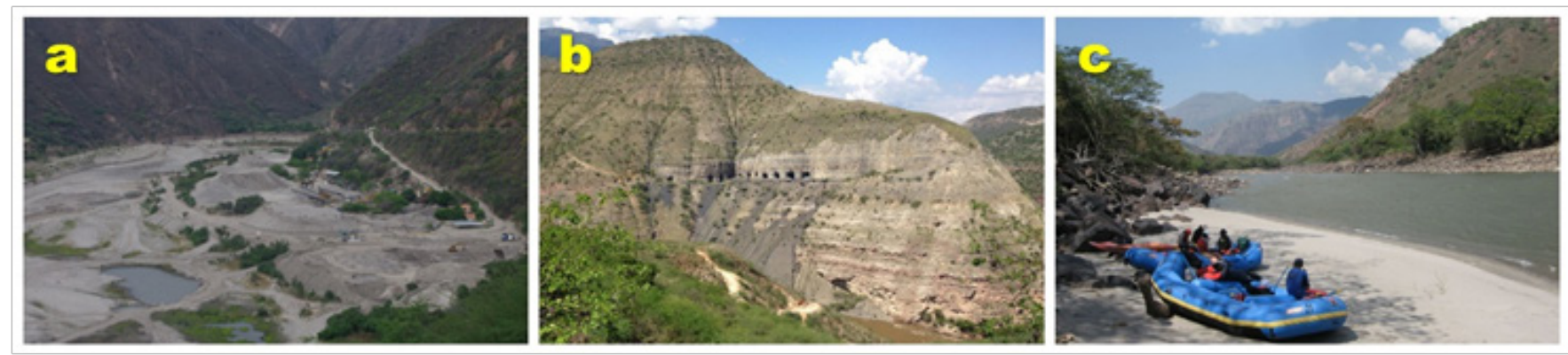

Figure 5 (A) Gravel and sand mining; (B) Gypsum mining; (B) Recreation.

\section{Geoeducation on the LBCR}

National Geographic has adopted the term "Geoeducation" to describe education about our world, providing students with a global understanding of how to work at local, regional and global levels. In the new modernization and different current societies, geoeducation plays an important role in integrating local communities to improve their quality of life, providing them with social equity. Recently, scientists and educators have shown interest in the development of geoeducation..$^{29-30}$ Most of the geosciences professionals consider that knowledge, experience and guidance are of vital importance to address many of the most acute environmental challenges facing society, however, few of these professionals are directly involved in sustainable development. ${ }^{31}$ A better understanding of geosciences and their field of action contributes to the awareness of geoconservation of great importance to ensure the protection of our planet. However, geoconservation actions must be supported by public legislation in the field of nature conservation and land planning. Geoeducation is definitely a strategy that contributes to the conservation of the territory and is considered to be the most effective way to guarantee the longterm preservation of the environment, providing a combination of understanding, attitudes and skills. It can promote the knowledge and significance on watersheds, in students from elementary to university levels based on the design and development of several geoeducation activities with the overall goal of expanding watershed education and awareness throughout the LBCR. One of the most important aspects to consider would be the design and development of a watershed program, with emphasis on the LBCR, which could be explored through a 3-day camp from which it would be possible to follow the course of the Chicamocha River, observing the numerous ways in which the river is used, river dynamics, and the ways in which it is transformed due to anthropogenic activity. Obviously there is no chair on watersheds in the student curriculum, therefore, geoeducation in students of colleges and universities would allow a transfer of knowledge about watersheds, connect children, adolescents and adults with the natural world to Become familiar with this and understand it better. The river basin program could also consider LBCR restoration activities, including visits to this basin of interest, collection of native plants and seeds, and revegetation. River restoration is a rapidlyexpanding field that has grown in response to increasing awareness of the scope and scale of human-induced ecosystem changes. ${ }^{32}$ The goals of restoration should be focused towards societal benefits. ${ }^{33,34}$ On the other hand, it is necessary to carry out presentations/demonstrations in classrooms in relation to water quality and how to keep safe drinking water, water properties, identification of aquatic insects as indicators of water quality, cycle of water and protection of riparian areas, among other aspects. Geo-education could also be extended to the training of teachers for the teaching of river basins. Finally, it is necessary to disseminate geoeducation activities in scientific events, which contributes to promoting regional interest in education, recreation and management of watersheds.
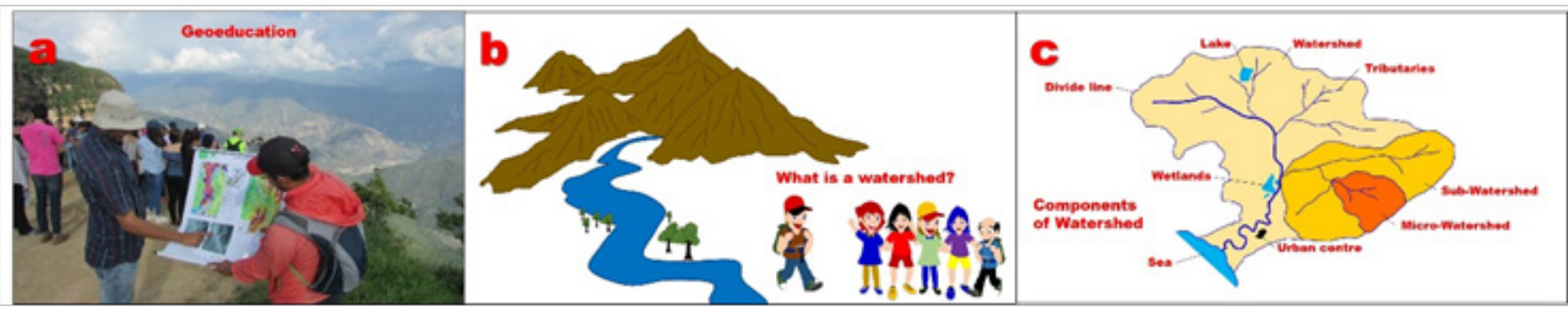

Figure 6 (A) Geoeducation; (B) Learning on what is a watershed? (C) Sketch of a watershed.

During recent times, several geoeducation activities have been developed in order to transfer the scientific knowledge on the significance of the Chicamocha River Canyon (Figure 6A). In the first instance, the geoeducation will start from the pre-existing knowledge in relation to what children, adolescents or adults know about what is a watershed? (Figure 6B), which represents a space defined by nature, based on the watershed and surface runoff. In general terms, the highest areas and the hills that surround a river define the river basin; there are located natural resources, urban centers, anthropogenic activities, infrastructure and services of the populations. A watershed represents a socio-geographic space where people and their organizations share the territory, their identities, traditions and cultures, socialize and work based on the availability of natural resources. Finally, they learn on the importance of a watershed to support the natural way of life for the existing fauna and flora, essential in the production and regulation of water, source of food for living beings as well as for agroindustry, source for the generation of energy and source of drinking water for humans and animals. The Chicamocha River forms 
part of a larger system (watershed), which is the land drained by the river and its tributaries. In general, rivers are large natural streams of water flowing in channels and emptying into larger bodies of water. Figure $6 \mathrm{C}$ illustrates the main characteristics of a watershed.

Geoeducation on the LBCR aims to promote the transfer of knowledge on watersheds in order to promote the socio-economic and sustainable development of the region. The inclusion of geosciences will reinforce current strategies of nature conservation to a more complete approach to protect all fauna and flora, rather than just protecting a single or a few species, within these habitats. The Chicamocha River Canyon is a territory, which can be a high-quality tourist destination by promoting the development of geoeducation, geotourism and geoconservation activities. There are numerous reasons that justify the need to design and develop programs of geoeducation on watersheds, which can be approached in a didactic and explanatory way in order to highlight not only the most important geological phenomena that have contribute to model the landscape of the Chicamocha River Canyon but also the different factors that have degraded the quality of water and, therefore, the environmental conditions and human health. In order to ensure the sustainable management of the territory by articulating agents that foster local development actions, stimulate the development of geoeducation programs, as well as good institutional practices that integrate efforts within the territory, and serve as a guiding mechanism for public policy. Geoeducation would be very useful to discuss on water, including where it comes from, how we use it, and how to conserve it. Therefore, we intend to educate the next generation about the value of water, and to encourage people and communities to understand the importance of rivers leads to them being more valued, and therefore more likely to be cared for and remain accessible to people.

Our society will have to face the future of water resources on a globalized planet, ${ }^{35}$ in which georeourses will be scarce and the impact on the environment and human health due to anthropogenic activity will be very high. Therefore, geoeducation emerges as an important alternative not only in the implementation of a culture of care and respect for our natural environment but also in preparation for future generations of water scientists. However, it is also important to consider networking within the region in order to promote the exchange of information and experiences. Some of the limitations that exist in the process translate into the lack of financial support, a follow-up program after training, institutional support to continue training and competition for major water resources development projects from organizations outside the region. ${ }^{36}$ Proper sustainable management brings great benefits for enjoying and appreciating the natural environment. The geoconservation of the LBCR and preventing pollution, contribute to the quality of life of the local communities and reduce the costs of government cleanup programs. On the other hand, the awareness of the importance of water quality to protect the water supply and habitat for people and animals that live downstream. Policy frameworks and campaigns for river conservation can be implemented in a number of ways. ${ }^{28,37}$ Initiatives that could be considered in the LBCR management plan could include: (1) facilities such as walkways, playgrounds sports areas, jogging and bicycle routes or gardens among others along the Chicamocha River as a strategy to protect from flooding and other natural disasters; (2) recreational opportunities such as fishing, canoeing or boating; (3) water ride tours on boats along the Chicamocha River; (4) observation and learning of habitats for wildlife and fish; (5) aesthetically pleasing surroundings with a decontaminated river that offers beauty in the landscape; (6) reduction costs for drinking water and cleaning up and protecting the environment; (7) improvement of public health and safety; (8) watershed management for prevention of flooding and other natural disasters and rational use of natural resources for the benefit of its inhabitants and the geodiversity and biodiversity associated with the river basin. However, it is essential to promote the participation of the regional environmental authorities in the feedback of the normative and technical proposals for the definition of the guidelines for the sustainable management of this river basin, as well as the adequate decision-making regarding the environmental management of the LBCR. A program of geoeducation can be performed, based on communication, environmental education and social mobilization as suggested by Obara et al.$^{38}$ by formal and nonformal education strategies by researchers and graduate students of the School of Geology of the Universidad Industrial de Santander, as geoeducation on watersheds (a study case of the LBCR) as the main topic of interest (Figure 7). Such initiative is important for strengthening the participation of different social actors, especially the local communities, which generally are at the margins of decision making in different public spaces dedicated to the management of river basins. ${ }^{39}$ Therefore, it is very important to create public policies that guarantee the continuity of the geoeducation process as a contribution in decision-making about the rational and sustainable use and management of water resources in the LBCR region.

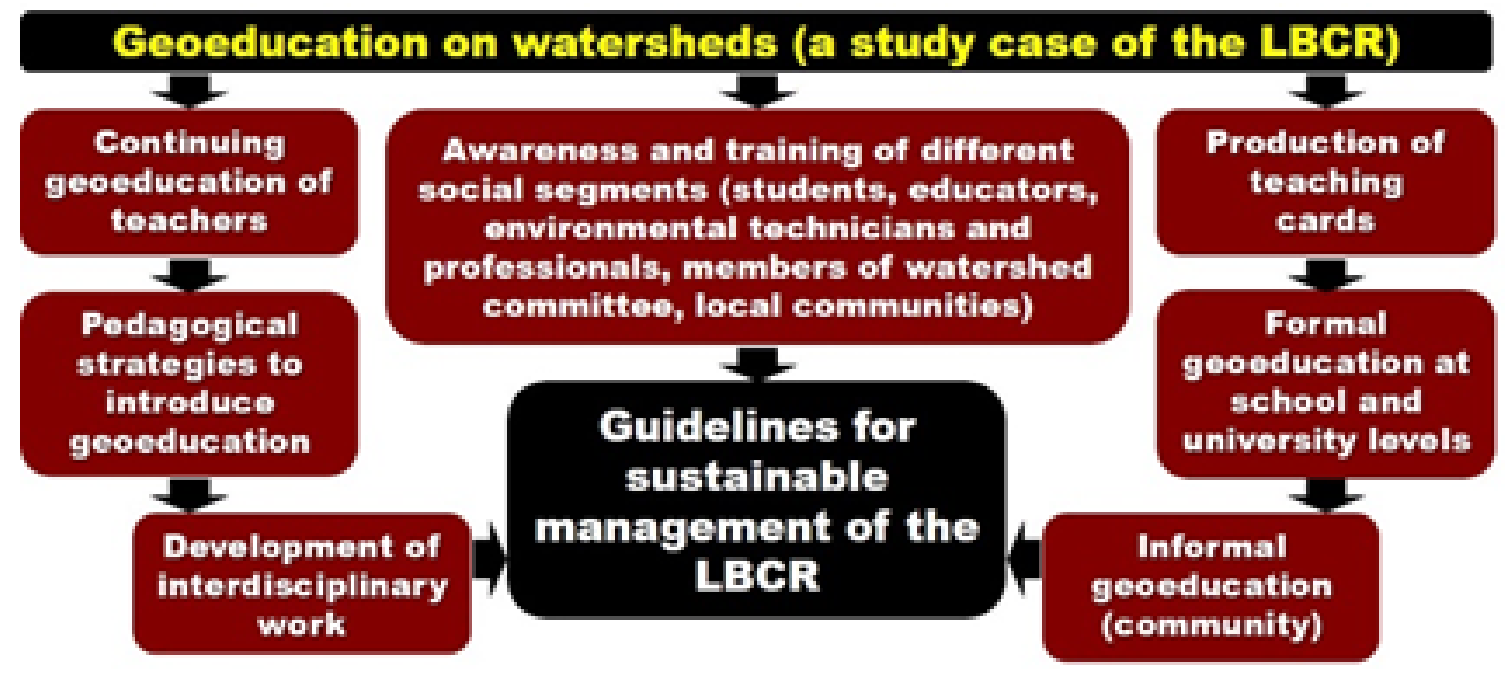

Figure 7 Workflow for the developemt of geoeducation on watersheds (adapted and modified after Obara et al). ${ }^{38}$ 


\section{Conclusion}

The protection of natural resources in the LBCR is essential to maintain the health and well-being of all living things, both now and in the future, this with the help of geoeducation, implementing in the people of the community and in the future tourist, the importance of the maintenance, conservation and care of the environment and the water resource, always bearing in mind the possible risk that the LBCR generates, being in an area with urban influence.

\section{Acknowledgments}

We gratefully acknowledge the members of the Research Group of Basic and Applied Geology from the Universidad Industrial de Santander for several discussions on the geoeducation. The authors would also like to acknowledge the anonymous referees for their critical and insightful reading of the manuscript and are most grateful to the above-named people and institutions for support.

\section{Conflicts of interest}

The author declares that there are no conflicts of interest.

\section{Funding}

None.

\section{References}

1. Pochat V. Principles of integrated water resources management: Bases for the development of national plans. Global Water Partnership. Central America and South America, 2008. p. 12.

2. Goldsmith R, Marvin R, Mehnert H. Radiometric ages in the Santander Massif, eastern Cordillera, Colombian Andes. US Geological Survey Professional Paper. 1971;750-D:D41-D49.

3. Ordóñez J. Petrology and geochemistry of the granitoids at the Santander Massif, Eastern Cordillera, Colombian Andes. Unpublished Master Thesis, Shimane University, Japan. 2003.

4. Ríos CA, Takasu A. Chemical zoning of garnet from the low-grade metamorphic rocks of the Silgará Formation, Santander Massif, Eastern Cordillera (Colombian Andes). Geosciences Reports of Shimane University. 1999;18:97-107.

5. Ríos CA, García CA. First occurrence of the three $\mathrm{Al}_{2} \mathrm{SiO}_{5}$ polymorphs in the Silgará Formation metapelitic rocks, southwestern Santander Massif, Eastern Cordillera, Colombian Andes. Boletín de Geología UIS. 2001;23(38):51-59.

6. Mantilla LC, Ordoñez J, Cepeda S, Ríos CA. Study of the paleofluids in the Silgará Formation and their relationship with deformation processes, Aratoca-Pescadero area (southwestern Santander Massif). Boletín de Geología UIS. 2001;23(38):69-75.

7. Ríos CA, García CA, Takasu A. Tectono-metamorphic evolution of the Silgará Formation metamorphic rocks in the southwestern Santander Massif, Colombian Andes. Journal of South American Earth Sciences. 2003;16(2):133-154.

8. Castellanos OM, Ríos CA. Geological itinerary of the crystalline basement of the southwestern region of the Massif of Santander. Java Publisher, 2008. p. 93.

9. Kammer A. Steeply dipping basement faults and associated structures of the Santander Massif, Eastern Cordillera, Colombian Andes. Geología Colombiana. 1993;18:47-64.
10. Serrano M, Pacheco B, Gualdrón J, et al. Basic study for the declaration of a protected natural area in the Chicamocha canyon, Jurisdiction CDMB, Bucaramanga, Colombia. Biocolombia Natural Heritage Conservation Foundation, Regional Autonomous Corporation for the Defense of the Bucaramanga Plateau CDMB. 2009. p. 283.

11. Albesiano S, Rangel JO, Cadena A. Vegetation of the Chicamocha River Canyon (Santander, Colombia). Caldasia. 2003;25(1):73-99.

12. Albesiano S, Rangel JO. Structure of the plant communities from Chicamocha canyon, 500-1200 masl; Santander, Colombia: a tool for conservation. Caldasia. 2006;28(2):307-325.

13. Díaz-Pérez CN, Puerto-Hurtado MA, Fernández-Alonso JL. Assessment of the habitat, populations and conservation status of the bellies (Cavanillesia chicamochae, malvaceae - bombacoideae). Caldasia. 2011;33(1):105-119.

14. Valencia-Duarte J, Trujillo LN, Vargas O. Vegetation dynamics in a semiarid enclave of the Chicamocha River, Colombia. Biota Colombiana. 2012;13(2):40-65.

15. Ángel LM, Ramírez MJ. Geological mapping and calculation of the water balance for the construction of the loading tunnel in the Chicamocha Hydroelectric Power Plant - Municipality of Aratoca, Santander. Undergraduate thesis, Pedagogical and Technological University of Colombia, Colombia. 2015.

16. Guzmán G. The Chicamocha River Canyon. In: Hermelin M, Editors. Landscapes and Landforms of Colombia. World Geomorphological Landscapes. Springer International Publishing, Cham, Switzerland. 2016;73-83.

17. Rangel JO, Franco P. Phytoecological observations in several life regions of the Central Cordillera of Colombia. Caldasia. 1985;14(67):211-249.

18. Watershed Analysis: What, How, Influencing Factors \& Applications.

19. Earth Explorer.

20. Zalewski M, Janauer GA, Jolankai G. Ecohydrology. A new paradigm for the sustainable use of aquatic resources. UNESCO, Paris UNESCO IHP Tech. 1997. p. 60.

21. Ekness P, Randhir TO. Effect of climate and land cover changes on watershed runoff: A multivariate assessment for storm water management. Journal of Geophysical Research: Biogeosciences. 2015;120(9):1785-1796.

22. Baron JS, Poff NL, Ammgermeier PL, et al. Meeting ecological and societal needs for freshwater. Ecological Applications. 2002;12(5):1247-1260.

23. Pickett S, Cadenasso M, Grove J. Urban ecological systems: linking terrestrial ecological, physical, and socioeconomic components of metropolitan areas. Annual Review of Ecology and Systematics. 2001;32:127-157.

24. Everard M, Moggridge H. Rediscovering the value of urban rivers. Urban Ecosyst. 2012;15(2):293-314.

25. Gurnell AM, Lee MT, Souch C. Urban Rivers: Hydrology, Geomorphology, Ecology and Opportunities for Change. Geography Compass. 2007;1(5):1118-1137.

26. Manrique-Abril FG, Manrique DA, Manrique RA, et al. Pollution of the upper Chicamocha River basin and some approaches to human health. Revista Salud, Historia y Sanidad. 2007;2(1):3-13.

27. Jiménez-Beltran AA, Cortes-Naranjo DA. Dynamic modeling of the water quality of the Chicamocha Rivers taking into account the discharge of wastewater from the city of Tunja. Undergraduate thesis, Universidad Santo Tomas, Colombia. 2016. 
28. Communities along Rivers: Importance of Community Networking to Preserve Local Rivers.

29. Mohamed K, Maksoud A, El-Shafeiy MA, Rashed TG. Geo-education in Egypt, ideas, challenges and visión. International Journal of Educational Policy Research and Review. 2014;1(2):14-20.

30. Lewis GM, Hampton SJ. Visualizing volcanic processes in SketchUp: An integrated geo-education tool. Computers \& Geosciences. 2015;81:93100

31. Stewart IS, Gill JC. Social geology - integrating sustainability concepts into Earth sciences. Proceedings of the Geologists' Association. 2017;128(2):165-172.

32. Clifford NJ. River restoration: Paradigms, paradoxes and the urban dimension. Sustain. Safe Water Supplies. 2007;7(2):57-68.

33. Dufour S, Piegay H. From the myth of a lost paradise to targeted river restoration: forget natural references and focus on human benefits. River Research and Applications. 2009;5(5):568-581.

34. Paetzold A, Warren PH, Maltby LL. A framework for assessing ecological quality based on ecosystem services. Ecological Complexity. 2010;7(3):273-281.
35. Thompson SE, Ngambeki I, Troch PA, et al. Incorporating studentcentered approaches into catchment hydrology teaching: a review and synthesis. Hydrology and Earth System Sciences. 2012;16:3263-3278.

36. Hughes DA. Hydrological education and training needs in sub-Saharan Africa: requirements, constraints and progress. Hydrology and Earth System Sciences. 2012;16:861-871.

37. Watersheds

38. Obara AT, Kovalski ML, Regina VB, et al. Environmental education for sustainable management of the basins of the rivers Pirapó, Paranapanema III and Parapanema IV. Brazil Journal of Biology. 2015;75(4):S137S147.

39. Jacobi PR. Participation in environmental management not Brazil: the committees of hydrographic bacias and the challenge of strengthening public collegiate spaces. In: Alimonda $\mathrm{H}$, Editors. The torments of the subject: contributions to a Latin American political ecology. Buenos Aires: Latin American Council of Social Sciences. 2006;205-230. 